\title{
An investigation into African-Caribbean academic success in the
}

\section{United Kingdom}

Jasmine Rhamie and Susan Hallam, Institute of Education, University of London.

Correspondence to Dr Susan Hallam, Institute of Education, University of London, 20 Bedford Way, London, WC1H OAA

E-mail: s.hallam@ioe.ac.uk 


\title{
An investigation into African-Caribbean academic success in the United
}

\section{Kingdom}

\begin{abstract}
While, there is a history of academic under-achievement among African-Caribbeans in the United Kingdom, some African-Caribbeans progress successfully through under-graduate and on to postgraduate studies. This research investigates the factors contributing to such academic success. Fourteen African-Caribbean professionals, male and female, aged between 23 and 40 years old, who had undertaken most of their compulsory education in United Kingdom schools, were interviewed. The findings suggest two possible models of success: a Home-School Model, which describes a continuous positive interaction between the home and school where both foster academic excellence and success and a Home-Community Model which suggests that the family and community together create a `sense of belonging' and acceptance and foster achievement and success, which compensate for low expectations and resources in the school. This suggests that academic success for a greater proportion of African-Caribbean children will become a reality when schools, the home and the community work together to develop and nurture academic achievement within a climate of excellence and high expectations.
\end{abstract}




\section{Introduction}

The under-achievement of African-Caribbean children in the United Kingdom has been well documented over the years. African-Caribbean children, in particular boys, have been over represented in the figures for exclusions from school, poor examination results, Emotional and Behavioural Difficulties (EBD), and receiving statements of Special Educational Need (Taylor, 1981; Fuller, 1980; Mirza, 1992). The situation has changed little in recent years.

In $1998 / 9$ the overall permanent percentage exclusion rate from school in the UK was $0.17 \%$ while the exclusion rates for Black-Caribbean, Black African and Black Other pupils were $0.59 \%, 0.20 \%$ and $0.49 \%$ respectively. These proportions represent some improvement from $1995 / 6$ when they were $0.92 \%, 0.35 \%$ and $0.53 \%$ respectively. Other minority groups have much lower rates: Indian, 0.04\%; Pakistani, 0.01\%; and Bangladeshi, 0.07\% (DfEE, 2000a). Despite the Department for Education and Employment (DfEE) encouraging Local Education Authorities (LEAs) and schools to work together to tackle the problem, the relatively high proportion of African-Caribbean exclusions continues.

In addition to featuring highly in exclusion figures, African-Caribbean children have since the 1960s been labelled and identified as underachievers (see Taylor, 1981; Tomlinson, 1983b for reviews). Research in the 1980's and 1990's reflected the earlier findings with African-Caribbean pupils continuing to make less progress on average than other pupils (Maughan et al, 1985; 
Mortimore, et al 1988; Drew and Gray, 1991; Plewis and Veltman, 1994; Gillborn and Gipps, 1996; Ofsted, 1999; Strand, 1999). Recent figures show some improvement from $18 \%$ of African-Caribbeans attaining 5 General Certificates of Secondary Education (GCSE) at Grades A*-C in 1989 to $37 \%$ in 2000 (DfEE, 2000b). While this is encouraging it has to be viewed within the context of the overall improvement in performance in GCSE Grades A* $-\mathrm{C}$ from $30 \%$ to $49 \%$. The relative level of underachievement of African-Caribbeans in comparison with other groups remains (DfEE, 2000b).

The data describing the performance of different ethnic minorities are inevitably confounded with other factors which are known to have an impact on achievement in school, for instance, parental education and socio-economic status. In addition, there are important gender differences. At secondary school, African Caribbean boys seem to be at greater risk of underachievement than girls because of a combination of irregular attendance (Fitzgerald et al., 2000), low teacher expectations, potential conflict with teachers (Wrench and Hassan, 1996; Gillborn and Gipps, 1996) and the high probability of being excluded as outlined above. Less than $25 \%$ of black boys acquire 5 GCSEs at Grade A*-C. They are likely to have GCSEs at grades lower than C or no GCSEs (Pathak, 2000). In contrast, African-Caribbean girls do well at school relative to their male and female working class peers as measured in terms of average exam performance at GCSE level (Mirza, 1992; Drew et al, 1992), although they may take longer to achieve their long-term educational aspirations.

In relation to their respective population sizes, ethnic minority groups are over represented in higher education, together currently accounting for $13 \%$ of undergraduates (Modood and Shiner, 1994, Pathak, 2000), although they are mainly found in the post 1992 universities. A 
disproportionate number are mature students. Approximately $60 \%$ of Black African male and African-Caribbean females start their degrees when they are aged over 25 (UCAS, 1999). Ethnic minority students are less likely (37\%) than white graduates (53\%) to obtain an upper second or first class honours degree (Pathak, 2000) and they are more likely to be unemployed following completion of their degree (Elias et al., 1999).

Despite the overwhelming evidence for African-Caribbean underachievement in the UK there has been very little research attempting to establish what might promote success. Tomlinson (1983a) found that parental encouragement and support, sympathetic teachers with high expectations and the support of the (Pentecostal) church were important factors. Bagley et al. (1979) and Osler, (1997) reported similar findings. Channer (1995) using a life history approach detailed the experiences of 12 individuals who had been successful in gaining a first degree. The research suggested that associations with the black church provided some but not all black Christians with a 'buffer against racism' (p. 190) but association with the church did not of itself guarantee academic success. Other factors were clearly implicated.

Some authors have argued that studies investigating and reporting academic success in AfricanCaribbeans may lead to a neglect of positive action to raise standards (Osler, 1997). However, research which consistently focuses only on negative educational outcomes provides an unbalanced perspective of the African-Caribbean community as a whole and reinforces negative stereotypes which, in themselves, contribute to the problem. Further, research drawing attention to underachievement and the high level of exclusions has been limited in its impact and change is slow. Recommendations have not resulted in the necessary change in attitudes and practice in schools to bring about an increase in standards. The aim of this study is to explore the factors that 
contribute to the academic success of African-Caribbeans who have continued their education to post-graduate level. It is hoped that this positive focus will provide suggestions for promoting success rather than ameliorating failure.

\section{Method}

The present study sought to elicit perceptions of the educational experiences of AfricanCaribbeans who had experience of education at post-graduate level. The research is embedded within a phenomenological framework. Phenomenology seeks to explore the way people experience their world (Tesch, 1990). This minimises the tendency to depend only on one theory to explain results and allows for increased 'theoretical flexibility' (Spinelli, 1989, p. 22). Semistructured interviews were adopted. These allowed participants free expression of their thoughts and feelings regarding their educational success and facilitated an in depth analysis of the factors which contributed to it. Following pilot work an interview schedule was developed which explored issues relating to academic qualifications, school experiences, home influences, out of school activities, personal and other miscellaneous factors.

The sample consisted of 14 African-Caribbean professionals who, with the exception of one Health Visitor with a professional qualification, were pursuing or had completed post-graduate studies. The participants ranged in age from 23 - 40 years old. Half of the sample was male and all were of Caribbean origin with the exception of one whose parents were Nigerian.

The interviews were taped and transcribed for analysis. Two researchers, working independently, categorised the statements derived from the interviews adopting the seven-stage process outlined by Cooper and Mclntyre ${ }^{1}$ (1993). There was complete agreement between them regarding the emergent categories. 


\section{Analysis and interpretation}

Four broad categories emerged from the data with a number of sub-categories and themes. These are set out in Figure 3.1. Home and Individual factors were expressed as having a role to play in contributing to the success of all the participants. School and Community factors were cited by some participants ( $86 \%$ and $64 \%$ respectively).

\section{Figure 3.1 about here}

\section{Home Factors}

All the respondents reported the importance of home influences on their success. Three subcategories emerged: Parents; Environment; and Family as Role Models and Mentors (see Table 3.1). The categories were not entirely independent.

Table 3.1 Table of Home Factors, Sub-Categories and Themes about here.

Parental Factors - Parental influence on educational attainment has been demonstrated as important in African-Caribbean success in earlier research (Tomlinson, 1983a; Gillborn and Gipps, 1996). This research identified more specific aspects of parental behaviour which contributed to high levels of achievement: Support and Encouragement, Guidance, Goals and Expectations and Knowledge. 
Support and Encouragement - All participants reported receiving parental support and encouragement.

'Parents were always encouraging and always supportive... It was just we heard a lot of....you need to be successful, you can be successful that was the philosophy'. (Lecturer/Teacher, 34 years)

Some parents tutored their children at home and monitored school work.

'When my father was around we had to do homework. He had his own curriculum. We'd come home do his and do the school one as well.' (Solicitor/School governor, 39 years)

In all cases parents stressed the importance of education. While, the extent of active support varied, even less well educated parents did what they could to encourage excellence and hard work, driving and motivating their children.

'... They made me sort of believe that education was important. It wasn't something I could just mess around with because I would regret it in years to come.' (LLM student, 23 years)

'... They always pushed me to do better.... I came home with a Maths result, I think I had 99\% and my Mum asked me what happened to the $1 \%$. They always wanted me to do better throughout school. There was verbal encouragement. If I finished my homework they would say go back and get more.' (PhD student, 24 years). 
All the respondents were immersed in a value system that sought to encourage, motivate and direct them towards making the most of education.

Guidance, Goals and Expectations - Parental influence was exerted through guidance, goal setting and high occupational expectations, e.g. lawyer, doctor. Parental determination for their children to do well was a theme that was echoed in many responses:

'I don't particularly think that my teachers were particularly supportive but because I had parents that were..... I was always sort of guided along the right path from the year nought. You know my father, my mum would sort of guide me by telling me roughly what would be the best educational path to take'. (Clinical Research Scientist, 26 years)

'.. My mother decided because she didn't get opportunities when she was young we were going to. So she decided immediately that we were going to do music. She always wanted us to play the piano... so that's the instrument she chose for us and we took to it.' (Lecturer/ Teacher. 34 years)

Knowledge -Parents tried to understand the British education system and what they needed to do to best support their child's progress through it taking account of their personality, abilities, strengths and weaknesses.

'...: My mother 's a teacher at $* * * * *$ University and she tracked my progress and said that it seems that you're weak in Economics, ...so she got me a private tutor for Economics...' (Lecturer/ Counsellor, 40 years) 
One respondent related the experience of her parents having to decide which of two secondary schools to send her, selective or non-selective.

'They had to sum up what sort of individual I was in terms of what I could cope with - always playing catch up or whether or not I needed to feel King Pin. I think my parents quite rightly decided that I needed to be at the top. That I could sustain that rather than feeling I was floundering at the bottom'. (Educational Psychologist, 31 years).

Other parents were aware of the difficulties inherent in the educational system for black children and attempted to overcome them. For example, some were reluctant to allow their children to become involved in extra-curricula sports activities because of the way that they perceived the system tended to steer African-Caribbean children into non-academic areas.

'I think my dad, particularly, was kind of clued in on, you know, the way in which the educational system sort of funnels black kids or pigeon holes black kids at an early age. And also he was determined that I would not fit in. He was very good like that'. (Clinical research scientist, 26 years)

While most parents trusted the education system they were committed to playing their part in negotiating their way through it to help their children.

Environment - An environment, encompassing a sense of belonging, and a loving, supportive, stable and secure home was cited by almost all respondents (93\%) as being crucial to their 
success.

'...Even though I went to live in Jamaica with my grandmother as a child I still had a fairly secure childhood in terms of feeling that somebody loved and appreciated me'. (Doctor, 30 years).

Parents also provided resources including books and encyclopaedias, other learning materials and finances to pay for private tuition and educational and culturally enriching trips. Parental occupation itself did not emerge as important, although a number of respondents referred to "general upbringing" which encompassed parental philosophy and child rearing practices.

Family as Role Models and Mentors - Relatives were important as role models and mentors.

My parents used to tell us about their siblings who had gone off to different universities... And they used to come to visit us and we had that challenge to know that we had relatives who were quite academic and we should do the same '. (Teacher/ MA student, 26 years)

For some the modelling process was direct with parents themselves involved in studying.

'I saw my parents working full time and I also saw them studying full time as well. So seeing that in your own environment, I think that can act as very strong motivating factors. I saw them working and I saw them studying. Both at the same time and I saw my Mum raise a family as well, as well as doing all the housework and stuff'. (Health Visitor, 38 years)

Having academically successful family members served to inspire some respondents, spurring 
them on to success by making them aware of what was possible.

\section{Individual Factors}

The second largest category to emerge from the data comprised themes relating to the characteristics of the individual. These were classified into five sub-categories: Motivation; Confidence; Awareness; Talent; and Deportment and Behaviour (see Table 3.2)

\section{Table 3.2 Table of Individual Sub-categories and Themes about here}

Motivation - As seen in Table 3.2, self motivation was reported as important by almost all respondents (93\%). Some were extrinsically motivated, having clear external goals, others were intrinsically motivated and enjoyed studying for its own sake. Self discipline, a desire to do well, strength and determination were recurring themes. Some of the respondents attributed their selfmotivation to internalising the demands of their parents:

‘.. I think my own motivation has developed from an extension of my parents, because I think when I became a teenager I used to hear my mum 's little voice: You should be studying and then I began to take that on as a sort of self corrective mould for myself '. (Teacher MA student. 26 years)

The desire to do well and having high expectations were also viewed as being internalised through experiences at home. 
'If they (the parents) are pushing you to be the best you can and do the best you can then you're not satisfied.....there is the sort of person who says go on how can I do more how can I advance. You're never satisfied. I think that's what I got from them'. (PhD student, 24 years)

Goal orientation emerged as a theme from more than half the respondents (71\%). Comments referring to the hope that there will be rewards at the end and to the single-mindedness that enabled the goals to be realised.

'I saw people around me messing around. I knew that I didn't want to be a part of that crowd. I knew that it meant being odd to certain people. But I was prepared to live that oddness to get what I wanted'. (Educational Psychologist, 31years)

Confidence - The respondents had confidence and determination that they could succeed.

`... I'm working extremely hard... and I consider every single day how I have to strive... It makes you stop and think before I actually put my head on the pillow, you can do it, you can reach it'. (Research Scholar, 32 years)

Some believed that this derived from internalising parental values, aspirations and beliefs about what was possible.

'My parents would say...you can do anything you want to do. It was having that belief that made you say, Yes, if I really put my heart into it, I can do it.' (Lecturer/Advisory Teacher, $\mathrm{PhD}$ student, 40 years) 
Awareness of self and circumstances - Respondents reported that they could step outside themselves and see their circumstances taking account of the wider picture (see Table 3.2). They were able to recognise their own vulnerable position as African-Caribbeans and the negative stereotyped perceptions that white society often had of them. They also recognised the importance of school and the education system and what was needed to successfully negotiate it.

'... I was shrewd enough to do enough that I needed to pass an exam. For example, I would put in the effort needed to 'get by'. (Solicitor / School Governor, 39 years).

Talent - Some indicated that they were perceived as being more able and that this affected the way they were treated in school.

'...Because I was perceived as being bright the teachers didn't give me an attitude like they gave my other friends. They would be a lot more helpful. The teachers were very supportive of me. They thought I was different or exceptional compared to the others so they always gave me a lot more time'. (Solicitor / School Governor, 39 years).

Deportment and behaviour - Two respondents commented on the importance of speech and behaviour which conformed to accepted school norms in helping to set them apart from other black children breaking teacher's stereotypical perceptions. These individual characteristics, often developed through home influences, were clearly important in determining the opportunities which were made available within the educational context. 


\section{School Factors}

Respondents' perceptions and assessments of their own schools reflected key determinants of effective schools cited by the Office for Standards in Education (OFSTED, 1995) (see Table 3.3).

Table 3.3 Table of School Sub-Categories and Themes about here

School Ethos and Type of School - Issues raised in relation to school ethos were often focused on the relative emphasis placed on academic success (see Table 3.3). This was sometimes attributed to the type of school attended, e.g. fee-paying or selective, where there was perceived to be a stress on academic excellence with teachers concentrating on the academic progress of students.

'...It's just the teaching is good. They encouraged all the girls into believing that they can achieve and do things... certainly at $* * * * * *$ you have to excel in everything, even games'. (LLM Student, 23 years).

Although, high expectations are an acknowledged feature of effective schools (Tizard et al., 1988; Mortimore et al., 1988), two respondents described the low expectations they observed when starting school in the UK having arrived from the Caribbean. Such comments have been echoed in other studies (Osler, 1997; Channer, 1995).

'...I remember the first day I went to school (in the United Kingdom)... It was totally unbelievable and there were kids in the secondary school who just about knew their tables stuff that we learnt in the Caribbean when we were 6 and 7. It took me a while to adjust downwards because I was 
very much up there in the Caribbean and in the end I had to level down in terms of what I learnt. I slowed down in my learning'. (Solicitor / School Governor, 39. years)

Teachers - The sub-category Teachers included the themes of high expectations, support and encouragement, and teachers' skills (see Table 3.3) Most respondents had some supportive and encouraging teachers.

'My teachers, they had the belief that you can do well, not all of them, but one or two'. (PhD student, 24 years)

One respondent who wanted to be a teacher described problems getting her Mathematics O' level which at that time was necessary for teacher training. She described:

'... I remember saying to him 'the Maths is too hard, I'll be a nursery nurse instead. He looked at me and said 'What! No way, you keep on with the Maths. You've got the ability to make a really good teacher. You will get the Maths before you leave.' And that just motivated me so much. I always remember him for that.' (MA Student. 36 years)

The descriptions of teachers referred to as 'good', 'excellent' or 'brilliant' were tempered by descriptions of others who were perceived as uncaring, unsupportive, hindering examination and career aspirations and in some cases being racist.

I wanted to do O level in History......and she absolutely refused. She would not allow me to do the O level...... I wanted to do both because you could do both in those days. She was a teacher that I 
never liked and I knew that it was simply because I was black that she didn't think that I would be able to do it. And that was one thing that I picked up on. As it happens I got a grade 3 but I went to sixth form and did the $\mathrm{O}$ level later in November the same year and passed with a grade B. I felt that I had proved her wrong'. (MA student, 36 years)

In some cases, in state schools, parents paid entry fees for external public examinations when teachers refused to enter their children. Where parents were paying school fees or the pupils attended selective schools such hindrances to academic progress were not in evidence and teachers were overwhelmingly described as supportive.

School Organisation - School organisation had two main themes, ability grouping through banding, streaming or setting and extra-curricular activities (see Table 3.3). The organisation of the school in terms of placement of students in ability groups emerged as an important factor. Some respondents described being moved to higher groups after initial inappropriate allocation.

'... They had me in the 'C ' class at school and I kept coming first, second or third in all of my classes and they moved me up and I was often hanging in there with the best of them. I even got much higher overall grades than some of those in the A class' (Health Visitor. 38 years)

African-Caribbean pupils are often placed in low attaining classes (for a review see Hallam and Tountounji, 1996). Some progress rapidly upwards through the system, others do not and experience a lack of academic challenge and stimulation.

Most respondents were involved in extra-curricular sporting activities, although parents 
sometimes limited engagement with sport emphasising academic work. Other common activities included music and chess. Participation in subject-oriented clubs was enjoyed to a lesser degree.

\section{Community Factors}

Community factors were less frequently raised in the interviews. They included Church and related activities; Music Tuition and activities; Community Projects and Cultural Activities; and access to Role Models and Mentors. A breakdown is provided in Table 3.4.

\section{Table 3.4 Table of Community Themes about here}

The church sub-category represented the respondents' participation in church organised clubs such as the Boys Brigade, Cubs and Scouts, Brownies and Girl Guides and Pathfinders (a mixed boy's and girl's club). Religious belief emerged as a theme as well as active regular involvement in church programmes. Nine (64\%) of the respondents had some Christian church involvement while growing up. Six were actively involved in church programmes, for three (21\%) involvement was restricted to the Boys Brigade or the Brownies. These activities provided opportunities to develop self confidence and self knowledge in and of their abilities, for instance, through arranging youth services in the church, reciting Bible texts or poetry before the congregation or performing musically.

'I've been fortunate in that I think my own sort of charisma and confidence that I've had through doing things in church that kind of thing has inspired me to go on and do something.' (Clinical Research Scientist, 26 years) 
Religious involvement included concepts such as the Christian work ethic. At least one respondent attributed success to this.

'The principles behind Christianity that is the work ethic: do well, don't cause trouble you know this kind of thing. You go to church, you behave yourself and sit still, you listen to what is being said. You discuss when it is time to discuss, you read and study before you go to church. All these things help towards helping you succeed in your own life.' (Health Visitor, 38 years)

Other themes that emerged related to the engendering of self belief and self worth. A small number of respondents attributed their success to God's will, guidance and blessing, others to a strong supportive atmosphere in church, which also provided opportunities to experience success through working on projects and for awards; developing self-discipline and a work ethic and enabling the respondents to experience praise for their accomplishments

'...My church. It fostered a strong supportive atmosphere that encouraged me to go for the mark. It is amazing how the church fulfilled that. It did it in more ways than one.' (Minster of Religion, 36 years)

Music Tuition - Several participants reported receiving private music tuition, usually piano, often outside school which involved taking national graded music examinations. Two respondents regularly performed publicly in a brass band or at a music school. Active participation in music seemed to encourage self-discipline and also provided an environment where there was clear evidence of success. 
Community Projects and Cultural Activities - Participation in sports, youth clubs, visits to the Caribbean, and visits to local cultural sites such as museums, libraries and art galleries were frequently mentioned. Just under half of the respondents had visited the Caribbean. This was beneficial as it provided positive role models of black people at all levels of society.

'It was great to see blacks who had achieved and each time you turned on the television there were black people on the television. It was brilliant. Yes, I loved it.' (Lecturer/Advisory teacher/ PhD student, 40 years).

'Black people having these wonderful big houses, even with pools. I remember that I thought it was great.' ( Health visitor, 38 years)

In the UK, one of the participants became involved in setting up a youth club for AfricanCaribbeans because of older siblings who were playing leading roles in their development. His sense of achievement and ownership came with his involvement.

`... I helped set up community projects like the *** youth club, running the community centre for kids and, so on. Black kids at that time had nowhere to go to so it was a bit of an innovation to have somewhere for black people to come to and do different projects like the education project looking at history in schools and things like that... ' (Solicitor / School Governor, 39 years).

Role Models and Mentors - Role models were to be found in the church, in older friends and, as reported above, during visits to the Caribbean. 
'I think that going to the mainly Afro-Caribbean church we had a lot of fairly well qualified people like a lot of nurses, teachers, skilled people there. I think it was good to see black people with jobs. Owning their own homes and driving their own cars. That was always there in the background. I think that was probably helpful'. (Health Visitor, 38 years)

'We had a chap who was a friend of the family. He was struggling to do $\mathrm{O}$ and A levels (national academic examinations) although he was quite a few years older than us. He was very encouraging and tried to give us focus as children'. (Minster of Religion, 36 year)

Role models within the community created a sense of confidence in and awareness of respondents' own abilities. They fuelled an awareness of the possibilities for success and played their part in spawning aspirations.

The evidence presented above suggests that a range of interacting factors contributed to the academic success of the participant African-Caribbeans. Examination of each individual case suggested two possible models of success: a Home-School based model; and a HomeCommunity based model.

\section{The Home-School Based Model}

The Home-School Based Model of Success (see Figure 3.2) shows the home, child and school grouped together as one. The school, effective with high academic expectations, is closely linked to the home and the child. There is a common purpose, shared language, culture and values. All 
pursue the same goal, that of academic success. Involvement in the community is important and is engaged in to provide a wider range of experiences but it is not central to success. A sense of purpose and achievement is fostered in the school and home and internalised by the child. The child having the major influences of its life in harmony and united in purpose is able to succeed academically. The experiences of four of the respondents seem to described by this model.

\section{Figure 3.2 about here}

\section{The Home-Community Based Model}

Figure 3.3 outlines the Home-Community Based Model of Success. Here the community and home together provide the child with a "sense of belonging", security and acceptance while emphasising the importance of achievement and success. The community is pivotal in providing the child with opportunities where he or she can experience success. The school is not a part of this circle. Its influence is separate and directly focused on the child. The child's experiences at school vary depending on the support and encouragement or lack of it of individual teachers who may respond to particular characteristics in the child. In this model, the school despite having low expectations does not deter the child from success as s/he has experienced it outside school. The child takes from the school what s/he needs to achieve the goals which have been formulated by influences outside school. In this model, the parents and representatives of the community who have been influential in the child's life, share the wider society's perspective of what constitutes success. The experiences of the majority of respondents fit within this model. The success of these children within the school system appears to be due to their experiences of learning outside of school. Such activities as preparing and studying to gain badges in church 
organised clubs, preparing presentations for church services, planning and following through a community project from start to finish, and the discipline and practice necessary for competence as a musician appear to help develop skills that are useful in school. Alongside these learning experiences comes the confidence and self worth that engenders self-efficacy in relation to other tasks. The rewards and positive feedback received serve to ignite a desire to continue in the same vein. The successes experienced in the supportive and caring environment of home and community (and sometimes church) provide evidence of what is possible and promote motivation to persevere at school.

\section{Figure 3.3 about here}

\section{Discussion}

This research used a small opportunity sample and the results and conclusions drawn must therefore be treated with caution. The data presented point to two models that might act as starting points for exploring the way that home, individual, school and community factors might interact in different ways to contribute to academic success in African-Caribbean children. While these models provided the best descriptions of the data presented above, no claims are made that they may account for the achievement of all academically successful African-Caribbeans. Indeed there may be those who have shared similar experiences to those of the participants but who have been unsuccessful academically. Further research focussing on a sample of African-Caribbeans with a wide range of levels of academic attainment will be required to establish the extent to which the models have explanatory value. 
The Home-School Model outlined in Figure 3.2 provides a description of the factors that contributed to the academic success of some African-Caribbean children. It suggests that where African-Caribbean children attend schools where expectations of academic success are high for all pupils they respond to this ethos and succeed academically. However, most African-Caribbean pupils attend inner city state schools (Pathak, 2000) where there has been a tendency for academic expectations to be low and resources to be inadequate.

The second model outlined in Figure 3.3 presents a scenario where African-Caribbean children are enabled to succeed despite low expectations in school and mixed responses to them by teachers. This model suggests that supportive, achievement-oriented community activities may, in conjunction with a supportive, education-focused home and motivated child, work together to provide a strong network that enables the child to succeed in school and remain focused on the goal of achieving despite the obstacles.

Socio-economic status is known to be one of the most powerful predictors of educational success. In inner city areas characterised by poverty and high unemployment, where AfricanCaribbeans often live, children from lower income families face exceptional obstacles en route to success irrespective of the values of their parents (Roberts, 1980). This research suggests that local communities can provide a 'sense of belonging' and opportunities to be successful which can demonstrate to young African -Caribbeans that it is possible for them to succeed. In the examples given here this support was provided by church and youth clubs. Recently, in black communities, a plethora of supplementary schools have been set up (Mirza, 1997; Reay and Mirza, 1997). While these are often portrayed as being a response to mainstream educational 
exclusion and poor practice in some schools, they are also places where blackness is the norm places where African-Caribbeans can develop the sense of belonging which seems to be important in achieving educational success (Mirza, 1997).

In the sample, there was a high incidence of private music tuition. This offered opportunities for enhanced self-esteem through the demonstration of achievement and receiving praise for it and may also have encouraged self-discipline and inculcated habits of independent study. Further research exploring the role of such extra-curricular activities in promoting success is indicated.

The research demonstrated the importance of successful role models for the participants. These included family members, friends of the family, members of the church attended, or were observed in visits to the Caribbean. Such successful role models are not available in the immediate environment of many African-Caribbeans. Overall, in the UK, there are relatively few examples of African-Caribbeans whose success has derived from high levels of education. This is reflected in education itself, where there is a lack of ethnic minority teachers, head teachers (TTA, 1999), governors and chairs of governors (Scanlon et al., 1999) and in higher education where there are few lecturers and almost no personnel in senior positions from ethnic minorities (HESA, 2000). In schools, a number of projects have been set up where young AfricanCaribbeans are supported by an older successful mentor (Kane, 1994). While there is anecdotal evidence of their success, there is no hard data (Pathak, 2000). The lack of successful academic role models in the immediate educational environment is likely to be a major contributory factor in African-Caribbean educational underachievement in the UK.

The development of the home-community model of success does not lay the burden of 
responsibility for academic achievement solely at the door of the home and community, but makes an expressly critical indictment of some schools, and the role of some of the teachers within them. That racism has been a feature in the interpretations of specific events in the school experiences of some respondents necessitates a re-evaluation of the role played by schools in the under-achievement of African-Caribbean pupils. Due to racism, black people, no matter how motivated are often denied the opportunity of an adequate level of education (Mirza, 1992; Gillborn, 1995). The findings underscore the need for effective schools, with high expectations, to become the norm rather than the exception. This government has implemented a range of policies designed to tackle underachievement in the inner cities, e.g. Education Action Zones, Excellence in Cities. The evidence reported in the introduction demonstrated that educational performance overall has improved but to date the initiatives have not been effective in raising academic achievement in the African-Caribbean community in comparison with other groups.

The participants in the research were selected to provide a sample which was balanced across gender. This serves to illustrate that African-Caribbean males can achieve high levels of academic success within the UK education system providing that the conditions are appropriate. Generally, however, African-Caribbean males are over represented in figures for exclusion from school and their underachievement is more marked than that of their female counterparts. African-Caribbean girls are more successful educationally, although in sociological terms they have been traditionally viewed as 'the most oppressed, the least visible, the least empowered and the most marginal of groups' (Mirza, 1997). Their relative success seems to derive from their active striving to be included within UK society, accessing available educational resources and through this creating opportunities for upward mobility. This contrasts with the male perspective which Mirza (1997) suggests assumes that racial equality can only be achieved through 
confrontation, mobilising in protest, riots, local politics and community organisations. She suggests that within the male African-Caribbean community, there is a perception that academic success is a form of collusion. In the research reported here gender did not arise as a differentiating factor. The factors mediating success were common for male and female participants. All demonstrated considerable determination to succeed. Male participants, although it was not explicitly stated, had rejected the notion that educational success was negatively associated with 'conforming' or 'colluding' with the mainstream and perceived it as desirable. This being so, raising the achievement of African-Caribbean boys may require interventions aimed at engendering and sustaining positive attitudes towards academic success and making their educational experiences more positive. While the evidence suggests that they have a positive attitude toward education in general (Fitzgerald et al., 2000), their reported negative experiences of school, particularly with some teachers, combined with strong peer pressure tends to lead to resistance and ultimately exclusion. Once excluded, the majority tend not to return to mainstream school (Parsons, 1996). Educational opportunities are then further damaged and negative attitudes towards society's values reinforced (Pathak, 2000). Addressing this will require schools to demonstrate that they are actively tackling racism, monitoring the progress of ethnic minorities (OFSTED, 1999), and enriching the curriculum so that it caters for and includes all pupils (Blair et al., 1998). There also needs to be a genuine demonstration that the educational achievement of African-Caribbeans will be rewarded in the employment market (Owen et al., 2000); that racial discrimination will cease; and that the UK is a truly multicultural society where equality of opportunity is a reality. This level of change will take time. In the interim, deeper investigation into the experiences of academically successful African-Caribbean males and females to establish more precisely the factors that have enabled them to succeed in school and to address the concerns expressed by them is crucial. 


\section{Footnote}

1. Cooper and McIntyre's (1993) seven stage process involves: 1. reading a random sample of scripts; 2 . identifying points of similarity and difference among these transcripts in relation to the research questions; 3. generating theories (on the basis of 2) describing emergent answers to research questions; 4. testing theories against a new set of transcripts; 5. testing new theories against transcripts already dealt with; 6. carrying all existing theories forward to new transcripts; 7. repeating above process until all data have been examined and all theories tested against all data.

\section{References}

BAGLEY, C., BART, M. \& WONG, J. (1979) `Antecedents of scholastic success in West Indian 10 year olds in London'. In G. VERMA and C. BAGLEY (Eds.) Race, Education and Identity. (London, Macmillan).

BLAIR, M. \& BOURNE, J with COFFIN, C., CREESE, A. \& KENNER, C. (1998) Making the difference: Teaching and Learning strategies in successful multi-ethnic schools, DfEE Research Report No 59. (London, DfEE)

CHANNER, Y. (1995) I Am a Promise: The School Achievement of British African-Caribbeans. (Stoke On Trent, Trentham Books). 
COOPER, P., \& MCINTYRE, D. (1993) Commonality in teacher's and pupil's perceptions of effective classroom learning. British Journal of Educational Psychology, 63, 381-399.

DEPARTMENT FOR EDUCATION AND EMPLOYMENT (2000a) Statistics of Education: Permanent Exclusions from maintained schools in England, Issue No 10/00. (London, DfEE)

DEPARTMENT FOR EDUCATION AND EMPLOYMENT (2000b) Youth Cohort Study: The activities and experiences of 16 year olds: England and Wales. (London, DfEE)

DREW, D. \& GRAY, J. (1991 ) `The black-white gap in examination results: a statistical critique of a decade's research'. New Community, 17, pp159- 172.

DREW, D, GRAY, J. and SIME, N. (1992) Against the odds: The education and Labour market experiences of young black people, Employment Department, Youth Cohort Series Report, No 19, June. (London: HMSO).

ELIAS, P., MCKNIGHT, A., PITCHER, J., SIMM, C \& PURCELL, K. (1999) Moving on: graduate careers three years after graduation. (Manchester, Higher Education Careers Service Unit/DfEE)

FITZGERALD, R. \& FINCH, S. (2000) Black Caribbean Young Men's Experiences of Education and Employment, Research Report 186. (London, DfEE) 
FULLER, M. (1980) 'Black Girls in a London Comprehensive'. In M. HAMMERSLEY \& P. WOODS (eds.) Life in School: The Sociology of Pupil Culture. (Milton Keynes, OUP).

GILLBORN, D. (1995) Race and Anti-racism in Real Schools. (Buckingham, Open University Press)

GILLBORN, D \& GIPPS, C. (1996) Recent research on the achievements of ethnic minority pupils (London, HMSO)

HALLAM, S \& TOUTOUNJI, I. (1996) What do we know about the grouping of pupils by ability? (London, Institute of Education, University of London)

HIGHER EDUCATION STATISTICS AGENCY (HESA) (2000) Resources of Higher Education Institutions 1998/99. (Cheltenham, HESA)

KANE, L. (1994) Mentoring for black students: improving equality of opportunity. Education and Training, 36, pp18-24.

MAUGHAN, B., DUNN, G., \& RUTTER, M. (1985) Black pupils’ progress in secondary schools: I Reading attainment between 10 and 14. British Journal of Developmental Psychology, 3(2), pp113-121

MIRZA, H. (1992) Young, Female and Black (London, Routledge)

MIRZA, H, S. (1997) Black women in education, In H.S. MIRZA, (Ed) Black British Feminism, 
(London, Routledge) pp. 269-277

MODOOD, T. \& SHINER, M. (1994) Ethnic Minorities and Higher Education: Why are there differential rates of entry? (London, PSI Publishing)

MORTIMORE, P., SAMMONS, P., STOLL, L., LEWIS, D. \& ECOB, R. (1988) School Matters: The Junior Years. (Wells: Somerset, Open Books)

OFFICE FOR STANDARDS IN EDUCATION, (1995) Characteristics of Effective Schools (London, HMSO)

OFFICE FOR STANDARDS IN EDUCATION, (1999). Raising the Attainment of Minority Ethnic Pupils. (London, HMSO)

OSLER, A. (1997) The Education and Careers of Black Teachers. (Buckingham, Open University Press)

OWEN, D., GREEN, A., PITCHER, J. \& MAGUIRE, M. (2000) Minority ethnic participation and achievements in education, training and employment, Research Report 225. (London, DfEE)

PARSONS, C (1996) Permanent exclusions from school in England, trends, causes and responses, Children and Society, 10, 177-186. 
PATHAK, S. (2000). Race Research for the Future: Ethnicity in Education, Training and the Labour Market. (London, DfEE)

PLEWIS, I, \& VELTMAN, M. (1994) Where Does All the Time Go? Changes in Infant Pupils' Experiences Since the Education Reform Act. (London, University of London, Institute of Education)

REAY, D. \& MIRZA, H. S. (1997) Uncovering genealogies of the margin: Black supplementary schooling, British Journal of Sociology of Education, 18(4), 477-499.

ROBERTS, K. (1980) Schools, Parents and Social Class. In M. CRAFT, J. RAYNOR, \& L. COHEN, (Eds.) Linking School and Home. (London, Harper and Row Publisher).

SCANLON, M., EARLEY, P., \& EVANS, J. (1999) Improving the Effectiveness of School Governing Bodies, Research report 111. (London, DfEE)

SPINELLI, E. (1989). The Interpreted World: An Introduction to Phenomenological Psychology. (London, Sage)

STRAND, S. (1999) Ethnic group, sex and economic disadvantage: associations with pupils' educational progress from baseline to the end of Key Stage 1, British Educational Research Journal, 25(2), 170-202.

TAYLOR, M. (1981 ) Caught Between: a review of research into the education of pupils of West 
Indian origin. (Windsor, NFER-Nelson)

TEACHER TRAINING AGENCY (1999). Initial teacher training performance profiles. (London, TTA)

TESCH, R. (1990). Qualitative Research. (New York, Falmer Press)

TIZARD, B., BLAT CHFORD, P., BURKE, J., FARQUHAR, C. \& PLEWIS, I. (1988). Young Children at School in the Inner City (London, Lawrence Erlbaum Associates)

TOMLINSON, S. (1983a) Black women In higher education- case studies of university women in Britain. In L. BARTON \& S. WALKER Race, Class and Education. (London, Croom Helm).

TOMLINSON, S. (1983b) Ethnic Minorities in British Schools: A Review of literature 1960-1982. (London, Heinemann Educational Books).

UNIVERSITY AND COLLEGES ADMISSIONS SERVICE (1999) Statistical Summary 1998-9 (Cheltenham, UCAS)

WRENCH, J. \& HASSAN, E. (1996) Ambition and marginalisation: A qualitative study of underachieving young men of Afro-Caribbean origin, DfEE Research Series No 31. (London, DfEE) 


\section{Jasmine Rhamie}

\section{BEd Dip Ed MA Psychology of Education}

Jasmine Rhamie is an experienced African-Caribbean teacher who has worked in a range of educational settings in both primary and secondary phases of education. She graduated from Newman College, University of Birmingham in 1983 and is currently completing her Doctoral studies at the Institute of Education, University of London where she completed an MA in the Psychology of Education with distinction in 1998. In addition to teaching she has also worked in several voluntary projects with children.

\section{Dr Susan Hallam}

\section{PhD, C.Psychol, AFBPsS FRSA}

Susan Hallam pursued careers as both a professional musician and a music educator before joining the Learning and Development Group at the Institute of Education, University of London in 1991. In 1999 she took up a post as Professor of Education at Oxford Brookes University returning to the Institute of Education in 2001. Her research includes work on exclusion from school, truancy, the effects of different kinds of ability grouping on educational outcomes, homework, pedagogy, student learning in Higher Education, learning in music and the effects of music on behaviour. 
Table 3.1 Home factors: sub-categories and themes

\begin{tabular}{|c|c|}
\hline & $\begin{array}{l}\% \text { of Respondents } \\
\text { referring to theme }\end{array}$ \\
\hline \multicolumn{2}{|l|}{ Parents: Support and Encouragement } \\
\hline - motivating and encouraging & 100 \\
\hline - sacrificing time and interests to be involved in the education of the respondent & 93 \\
\hline - emphasising the importance of education and schooling & 86 \\
\hline - taught at home or tutors provided & 71 \\
\hline - encouraging and monitoring school and homework & 71 \\
\hline - supportive of respondent & 71 \\
\hline - supportive of school & 57 \\
\hline - pushing respondent to do better & 21 \\
\hline $\begin{array}{l}\text { - acting independently, not solely relying on teachers' assessments of } \\
\text { respondents }\end{array}$ & 14 \\
\hline \multicolumn{2}{|l|}{$\begin{array}{l}\text { Parents: Guidance, goals and expectations } \\
\end{array}$} \\
\hline - high expectations & 86 \\
\hline - guiding educational path with clear goals & 43 \\
\hline - determination to see the respondent through education & 21 \\
\hline \multicolumn{2}{|l|}{ Parents: Knowledge } \\
\hline - knowledge and understanding of the education system & 43 \\
\hline - knowledge and understanding of the respondent & 21 \\
\hline \multicolumn{2}{|l|}{ Environment } \\
\hline - providing resources, security and loving support & 93 \\
\hline - general upbringing & 36 \\
\hline - 'middle class' upbringing & 29 \\
\hline - disciplined and strict environment & 29 \\
\hline \multicolumn{2}{|l|}{$\begin{array}{l}\text { Family as Role Models and Mentors } \\
\end{array}$} \\
\hline - parents as mentors and role models & 43 \\
\hline - academic relatives and siblings & 43 \\
\hline - relatives as mentors & 7 \\
\hline
\end{tabular}


Table 3.2 Individual subcategories and themes

\begin{tabular}{|l|c|}
\hline \multicolumn{1}{|c|}{ Individual Factors } & $\begin{array}{l}\% \text { of } \\
\text { referring to the theme }\end{array}$ \\
\hline \multicolumn{2}{|c|}{ Motivation } \\
\hline - self-motivated & 93 \\
\hline - goal oriented and focused & 71 \\
\hline - strength, determination and will power & 50 \\
\hline - desire to do well and work hard & 50 \\
\hline - enjoy studying & 21 \\
\hline - self-discipline & 7 \\
\hline \multicolumn{2}{|c|}{ Confidence } \\
\hline - self-belief, confidence and faith in oneself \\
\hline \multicolumn{2}{|c|}{ Awareness } \\
\hline - aware of the education system and the importance of schooling \\
\hline - feeling loved and appreciated Talent \\
\hline - awareness of black culture and stereotypes \\
\hline \multicolumn{2}{|c|}{ Deportment and behaviour } \\
\hline - natural ability & 71 \\
\hline \multicolumn{2}{|c|}{21} \\
\hline - good speech and behaviour & 14 \\
\hline
\end{tabular}


Table 3.3 School sub-categories and themes

\begin{tabular}{|c|c|}
\hline & $\begin{array}{l}\% \text { of respondents referring to } \\
\text { the theme }\end{array}$ \\
\hline \multicolumn{2}{|c|}{ Ethos and type of school } \\
\hline - Positive atmosphere & 64 \\
\hline - Ethos: academic excellence & 36 \\
\hline - Very good state school & 21 \\
\hline - Fee paying or selective school & 14 \\
\hline - Primary schooling in the Caribbean & 14 \\
\hline \multicolumn{2}{|c|}{ Teachers } \\
\hline - Supportive and encouraging & 64 \\
\hline - Abilities & 35 \\
\hline - Expectations & 14 \\
\hline \multicolumn{2}{|c|}{ School organisation } \\
\hline Banding and streaming & 29 \\
\hline \multicolumn{2}{|l|}{ Extra-curricula activities: } \\
\hline - Sports & 71 \\
\hline - Music/drama & 50 \\
\hline - Extra English and Maths & 21 \\
\hline - Chess clubs & 14 \\
\hline
\end{tabular}


Table 3.4 Community themes

\begin{tabular}{|c|c|}
\hline & $\begin{array}{l}\% \text { of respondents } \\
\text { referring to the theme }\end{array}$ \\
\hline \multicolumn{2}{|c|}{ Church } \\
\hline - Regular, active involvement in programmes & 43 \\
\hline - Religious beliefs & 36 \\
\hline - Clubs & 36 \\
\hline - Sense of belonging and support network & 29 \\
\hline \multicolumn{2}{|c|}{ Music Tuition } \\
\hline - Tuition & 64 \\
\hline - Additional band or music involvement & 14 \\
\hline \multicolumn{2}{|c|}{ Community projects and cultural activities } \\
\hline - Positive experiences of the Caribbean & 43 \\
\hline - Visits to libraries, museums, art galleries, etc. & 14 \\
\hline - Sports & 14 \\
\hline - Youth clubs & 7 \\
\hline \multicolumn{2}{|c|}{ Role models and mentors } \\
\hline - Within the church community & 36 \\
\hline - Older friends & 29 \\
\hline - From the Caribbean & 21 \\
\hline
\end{tabular}

